\author{
Abstracta Iranica \\ Abstracta Iranica Revue bibliographique pour le domaine irano-aryen \\ Volume 34-35-36 | 2017 \\ Comptes rendus des publications de 2011-2013
}

\title{
A. Destrooper-Georgiades. Le reflet des crises de l'époque achéménide dans le monnayage chypriote
}

\section{Astrid Nunn}

\section{(2) OpenEdition}

Journals

Édition électronique

URL : http://journals.openedition.org/abstractairanica/41548

DOI : 10.4000/abstractairanica.41548

ISSN : 1961-960X

Éditeur :

CNRS (UMR 7528 Mondes iraniens et indiens), Éditions de l'IFRI

\section{Référence électronique}

Astrid Nunn, «A. Destrooper-Georgiades. Le reflet des crises de l'époque achéménide dans le monnayage chypriote », Abstracta Iranica [En ligne], Volume 34-35-36 | 2017, document 23, mis en ligne le 15 juillet 2016, consulté le 30 septembre 2020. URL : http://journals.openedition.org/abstractairanica/41548 ; DOI : https://doi.org/10.4000/abstractairanica.41548

Ce document a été généré automatiquement le 30 septembre 2020

Tous droits réservés 


\title{
A. Destrooper-Georgiades. Le reflet des crises de l'époque achéménide dans le monnayage chypriote
}

\author{
Astrid Nunn
}

\section{RÉFÉRENCE}

A. Destrooper-Georgiades. « Le reflet des crises de l'époque achéménide dans le monnayage chypriote ». Trans., 40, 2011, p. 47-59.

1 Les monnaies font écho aux crises politiques et économiques. Ainsi une monnaie portant les types d'Evagoras Ier de Salamine et de Paphos pourrait refléter l'alliance de Salamine et de Paphos contre le roi de Kition. La crise politique de Salamine entre 450 et $400 \mathrm{av}$. J.-C. se remarque dans le manque de monnaies. D'autre part le surfrappage à Kition et Paphos indique un manque du métal argent et donc une crise économique. En outre, les monnaies d'Evagoras Ier trouvées en Cilicie semblent confirmer son expédition en Cilicie.

\section{AUTEURS}

\section{ASTRID NUNN}

Université de Munich 